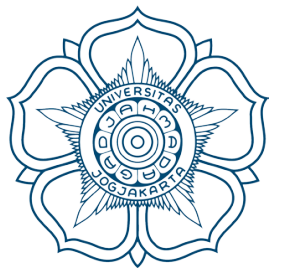

Judul Naskah

: NILAI-NILAI KEARIFAN LOKAL YANG DITERAPKAN

DALAM PENGELOLAAN TANAH PARIWISATA SRI

GETHUK DI BLEBERAN, PLAYEN,GUNUNG KIDUL

Nama Penulis : Agus Sudaryanto

MIMBAR HUKUM

$\begin{array}{ll}\text { DOI } & : \text { http://doi.org/10.22146/jmh.29153 } \\ \text { Penerbit } & : \text { Fakultas Hukum Universitas Gadjah Mada } \\ \text { URL } & : \text { jurnal.ugm.ac.id/jmh } \\ \text { E Issn } & : 2443-0994 \\ \text { P Issn } & : 0852-100 x\end{array}$




\title{
NILAI-NILAI KEARIFAN LOKAL YANG DITERAPKAN DALAM PENGELOLAAN TANAH PARIWISATA SRI GETHUK DI BLEBERAN, PLAYEN,GUNUNG KIDUL*
}

\author{
Agus Sudaryanto* \\ Departemen Hukum Adat, Fakultas Hukum, Universitas Gadjah Mada \\ Jalan Sosio Yusitisia No. 1, Bulaksumur, Sleman, D.I. Yogyakarta 55281
}

Abstract

The management of the land of Sri Gethuk waterfall in Bleberan Playen Gunungkidul should be by applying local wisdom values locally. The results showed, first, the value of local wisdom used in the management of Sri Gethuk tourism is the value of innovation, persistence value, the value of togetherness, the value of musyawarah, the value of locality and religius value. Secondly, the Solution if there is a conflict of value in the management of Sri Gethuk tourism is done through compromise, deliberation or wisdom.

Keywords: local wisdom, value, management, tourism.

\section{Intisari}

Pengelolaan tanah Wisata Air Terjun Sri Gethuk di Bleberan Playen Gunungkidul seharusnya dengan menerapkan nilai kearifan lokal setempat. Hasil penelitian menunjukkan bahwa pertama, nilai kearifan lokal yang digunakan dalam pengelolaan wisata Sri Gethuk adalah nilai inovatif, nilai kegigihan, nilai kebersamaan, nilai musyawarah, nilai lokalitas dan nilai religius. Kedua, Solusi jika terjadi benturan nilai dalam pengelolaan wisata Sri Gethuk dilakukan melalui kompromi, musyawarah atau kebijaksanaan/ kearifan.

Kata Kunci: kearifan lokal, nilai, pengelolaan, wisata.

\section{Pokok Muatan}

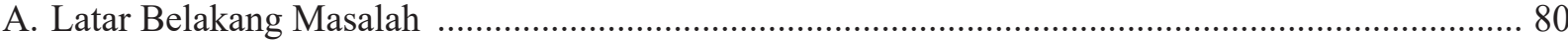

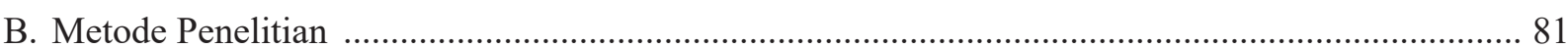

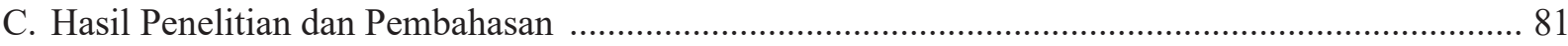

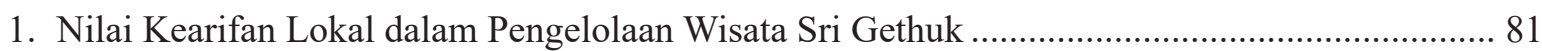

2. Solusi Jika Terjadi Benturan Nilai Dalam Pengelolaan Wisata Sri Gethuk .................................. 86

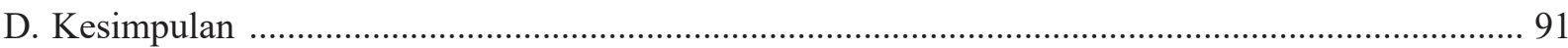

\footnotetext{
Penelitian Dana Hibah Unit Riset dan Publikasi Fakultas Hukum Universitas Gadjah Mada Tahun 2017.

** Alamat korespondensi: agussudaryantohk@yahoo.com.
} 


\section{A. Latar Belakang Masalah}

Sejak Otonomi Daerah dilaksanakan, banyak wilayah di Indonesia yang menggali potensi daerahnya agar mampu meningkatkan Pendapatan Asli Daerah (PAD). Peningkatan PAD tersebut menjadi kewajiban karena pemerintah pusat memberi batasan anggaran di tiap daerah. Akibatnya, apabila daerah tidak bergerak untuk menggali potensi yang ada di daerahnya, maka berakibat pada pembangunan wilayahnya yang akan menjadi lambat bahkan menjadi tertinggal dibandingkan dengan wilayah lain. Peraturan perundang-undangan yang dijadikan dasar pelaksanaan otonomi daerah di antaranya Pasal 18 Undang-Undang Dasar Negara Republik Indonesia Tahun 1945 (UUD NRI Tahun 1945), UU No. 23 Tahun 2014 tentang Pemerintahan Daerah (serta perubahannya), dan peraturan pelaksanaannya. Peraturan tersebut sebagai landasan hukum untuk mendorong otonomi daerah dalam rangka meningkatkan kesejahteraan rakyat.

Daerah Istimewa Yogyakarta (DIY) termasuk daerah dengan PAD rendahjika dibadingkan provinsi lainnya, seperti Kalimantan Timur, DKI Jakarta, Papua atau Riau. Akan tetapi, DIY mendapatkan subsidi dari pusat yang cukup memadai, sehingga pembangunan daerah dapat berjalan sebagaimana mestinya. Meskipun demikian, untuk meningkatkan pembangunan infrastruktur daerah, diperlukan tambahan dana yang signifikan. Akibatnya, kepala daerah setempat didorong untuk memutar otak untuk meningkatkan PAD di wilayahnya. Ketersediaan sumber daya alam di DIY terbatas, namun sumber daya manusia relatif maju. Kepala daerah atau bupati di DIY kemudian berloma-lomba menggali potensi wisata yang selama ini belum digarap dengan baik. Sejalan dengan Yogyakarta sebagai tujuan pariwisata setelah Bali, maka ide penggalian objek wisata itu disambut baik oleh banyak pihak, karena tidak hanya pemerintah daerah, tetapi pelaku bisnis di bidang pariwisata, wisatawan serta masyarakat setempat. Berbagai pihak yang terlibat dalam aktivitas pariwisata diharapkan dapat meningkatkan kesejahteraan.

Gunungkidul sebagai salah satu Provinsi DIY berupaya meningkatkan kesejahteraan warganya dengan cara peningkatkan PAD salah satunya melalui sektor pariwisata. Berbagai tempat yang potensial dikembangkan untuk menarik wisatawan cukup mendapatkan perhatian yang signifikan seperti Goa Pindul, Pantai Siung, Gunung Api Purba Nglanggeran dan Air Terjun Sri Gethuk. ${ }^{1}$ Sebagai gambaran kontribusi bidang pariwisata untuk PAD Gunungkidul pada tahun 2016 adalah sebesar Rp22.698.500.000,00, dari total PAD senilai Rp187.400.000.000,00. ${ }^{2}$ Berdasarkan keadaaan sumber daya alamnya Gunungkidul masih potensial mengembangkan daya tarik wisatawan untuk datang dan menikmati wisata alamnya.

Selain dampak positif pariwisata yang dapat menyejahterakan masyarakat, pariwisata juga dapat berdampak pada terbukanya wilayah dan masyarakat untuk berinteraksi dengan wisatawan (orang luar). Dalam pengelolaan pariwisata hubungan sosial yang terkait dengan hubungan antara orang perseorangan, antara kelompok-kelompok manusia maupun perseorangan dengan kelompok manusia merupakan keniscayaan. ${ }^{3}$ Hal tersebut semakin ditunjang dengan globalisasi yang menyeruak sampai ke wilayah desa-desa di Indonesia termasuk Kabupaten Gunungkidul sehingga menyebabkan nilai-nilai lokal yang sudah eksis harus berhadapan dengan nilai-nilai baru sebagai dampak globalisasi. Komersialisasi, individualisme maupun materialisme berpotensi mempengaruhi cara pandang masyarakat. Akibatnya, terjadi benturan antara nilai-nilai lokal masyarakat setempat dengan nilai-nilai baru yang datang dari

\footnotetext{
Kania Kismadi, "7 Tempat Wisata di Gunungkidul Yang Tidak Boleh Dilewatkan Para Pencari Andrenalin",https://www.skyscanner.co.id/ berita/7-tempat-wisata-di-gunung-kidul-jogja, diakses 04 April 2017.

Sumadiyono, "PAD Gunungkidul: Pemkab Optimis Target 2016 Tercapai”, http://www.harianjogja.com/baca/2016/07/20/pad-gunungkidulpemkab-optimistis-target-2016-tercapai-738456, diakses 04 April 2017, dan lihat juga David Kurniawan, "PAD Gunungkidul Kelebihan Target Rp 18.4 M", http://semarang.bisnis.com/read/20170330/9/93096/pad-gunungkidul-kelebihan-target-rp184-miliar, diakses 04 April 2017.

Soerjono Soekanto, 1999, Sosiologi Suatu Pengantar, PT Raja Grafindo Persada, Jakarta, hlm. 67.
} 
luar. Kondisi tersebut apabila tidak disikapi dengan arif dan bijaksana akan menimbulkan konflik, baik horizontal maupun vertikal.

Nilai-nilai kearifan lokal dalam pengelolaan tanah yang digunakan untuk tempat Wisata Sri Gethuk di Desa Bleberan perlu untuk digali. Hal tersebut dikarenakan potensi konflik dan kepentingan dapat muncul dari pengelolaan objek pariwisata tersebut. Wisata Sri Gethuk berdiri diatas wilayah yang kepemilikan tanahnya berbeda. Berdasarkan keterangan salah satu tokoh Masyarakat Desa Bleberan dinyatakan bahwa tanah yang dijadikan wilayah Wisata Sri Gethuk tidak dikuasai atau dimiliki para pihak secara tunggal tetapi beragam, yaitu ada tanah yang merupakan milik pribadi, milik pemerintah desa atau Pemerintah Daerah Kabupaten Gunungkidul maupun Pemerintah Daerah Kabupaten Bantul. ${ }^{4}$ Berdasarkan keanekaragaman kepemilikan (penguasaan) tanah tersebut dan ditunjang adanya arus globalisasi sulit dihindari adanya kepentingan yang dilandasi nilai yang berbeda sehingga potensi konflik sangat rentan muncul dalam pengelolaan tanah untuk kepentingan wisata di Sri Gethuk Gunungkidul.

Berdasarkan latar belakang sebagaimana diuraikan di atas, maka dapat dirumuskan permasalahan sebagai berikut : Pertama, apa saja nilai-nilai kearifan lokal yang digunakan dalam pengelolaan tanah pariwisata Sri Gethuk di Bleberan, Playen, Gunung Kidul? Kedua, bagaimana solusi jika terjadi benturan antara nilainilai dari luar wilayah dengan nilai kearifan lokal setempat?

\section{B. Metode Penelitian}

Jenis penelitian ini adalah penelitian yuridis empiris karena yang diutamakan pengumpulan data primer yang diperoleh langsung dari sumbernya, yaitu dari para responden dan narasumber. ${ }^{5}$
Selanjutnya, dilengkapi dengan data sekunder yang diperoleh melalui studi pustaka. Fokus penelitian ini adalah nilai-nilai kearifan lokal yang digunakan dalam pengelolaan tanah pariwisata Sri gethuk di Bleberan, Playen, Gunung Kidul.

Pengumpulan data lapangan dilakukan melalui teknik non probability sampling khususnya purposive sampling. ${ }^{6}$ Jumlah keseluruhan subjek penelitian sejumlah 13 (tiga belas) orang; terdiri dari 9 (sembilan) responden, yaitu Ketua Unit Wisata BUM Desa, 1 (satu) Petugas Panitikismo Kraton Yogyakarta, 3 (tiga) Tokoh Masyarakat, 4 (empat) pemilik dan 1 (satu) Tokoh Pemuda. Narasumber sebanyak 3 (tiga) orang, terdiri 1 (satu) Tokoh Agama, 1 (satu) Staf Dinas Kehutanan dan Perkebunan DIY dan Kepala Desa Bleberan. Data yang terkumpul dianalisis secara kualitatif. Penarikan kesimpulan digunakan logika induktif karena dibangun dari data lapangan dan bermuara pada kesimpulan umum. ${ }^{7}$

\section{Hasil Penelitian dan Pembahasan \\ 1. Nilai Kearifan Lokal dalam Pengelolaan Wisata Sri Gethuk}

\section{a. Nilai Inovatif}

Asal muasal ide untuk membuat Wisata Air Terjun Sri Gethuk bukan diinisiasi oleh masyarakat Desa Bleberan, melainkan warga pendatang (bukan penduduk asli Bleberan). Ketika ada kesempatan berada di desa tersebut mengajak diskusi dengan kepala desa tentang kemungkinan dibukanya wisata air terjun Sri Gethuk. Masalah ini dikatakan oleh mantan Kepala Desa Bleberan sebagai berikut:

"Awal mula adanya usulan agar Desa Bleberan membuka wisata air terjun Sri Gethuk adalah adanya rembugan tukar kawruh (diskusi) antara pihak Kepala Desa Bleberan dengan pegawai

\footnotetext{
Hasil wawancara dengan Tri Harjono, tokoh masyarakat Desa Bleberan, Kecamatan Playen, Kabupaten Gunungkidul, 24 November 2016. Maria SW Sumardjono, "Metodologi Penelitian Ilmu Hukum”, Makalah, Universitas Gadjah Mada, Yogyakarta, 2007, hlm. 13.

Burhan Ashofa, 2001, Metode Penelitian Hukum, Rineka Cipta, Jakarta, hlm. 87-88.

M. Burhan Bungin, 2007, Penelitian Kualitatif Komunikasi,Ekonomi, Kebijakan Publik dan Ilmu Sosial Lainnya, Kencana Prenada Media Group, Jakarta, hlm. 143.
} 
Departemen Kehutanan Jakarta yang bernama bapak Sukandi sekitar 1974. Wacana pembukaan desa wisata ini dikemudian dipikir dan disampaikan dalam pertemuan-pertemuan dengan staf desa dan tokoh-tokoh masyarakat Desa Bleberan". 8

Masalah tersebut, dikuatkan oleh pernyataan salah satu Kepala Dukuh Menggoran sebagai berikut:

"Salah satu warga masyarakat desa ini yang bekerja di Kehutanan Jakarta, awalnya membuka wacana untuk menjadikan Desa Bleberan ini sebagai salah satu desa wisata agar masyarakatnya dapat dampak meningkat kesejahteraannya. Ketika itu warga belum bisa membayangkan seperti apa jadinya jika menjadi kenyataan. Namun sebagai pamong masyarakat, harus mendukung ide atau gagasan yang baik". ${ }^{9}$

Berdasarkan wawancara di atas, dapat ditegaskan bahwa pemrakarsa agar Desa Bleberan dijadikan desa wisata melalui Air Terjun Sri Gethuk adalah berasal dari tokoh masyarakat yang peduli terhadap peluang usaha yang ada di wilayah desa tersebut. Para pemuka masyarakat menyadari bahwa potensi desa tersebut sudah ada, tinggal menghadapi tantangan untuk merealisasikannya. Wawasan inovatif dan visioner merupakan faktor yang esensial bagi terwujudnya Desa Wisata Air Terjun Sri Gethuk. Pandangan yang inovatif dan jauh ke depan (visioner) terkandung makna bahwa seseorang yang memilikinya mampu memprediksi atau mengetahui sesuatu yang belum terjadi, dalam bahasa Jawanya menurut Khakim disebut dengan istilah waskita. $^{10}$

Para pemuka Desa Bleberan memiliki harapan ke depan atas terwujudnya pembangunan wisata di desanya. Hal tersebut sesuai dengan pendapat Hartono bahwa dalam melakukan pembangunan yang berencana itu harus mempunyai visi ke masa yang akan datang atau berorientasi masa depan (forward looking). ${ }^{11}$ Artinya, tokoh-tokoh masyarakat memiliki nilai inovatif dalam rangka mewujudkan desa wisata. Desa wisata tidak dapat terwujud tanpa adanya nilai inovatif untuk menyikapi dan menindaklanjuti peluang otonomi daerah yang ada.

\section{b. Nilai Kegigihan}

Tahap awal mula merealisasikan Wisata Air Terjun Sri Gethuk bagi pemuka Masyarakat Bleberan tidak semudah yang dibayangkan. Jika digambarkan keadaannya tidak semudah membalikkan tangan dalam menyatukan pandangan dan tekad yang kuat warga masyarakat untuk mewujudkan desa wisata. Setelah melakukan sosialisasi secara terus menerus melalui berbagai pertemuan baik formal maupun non formal dengan berbincang santai saat ketemu, akhirnya sebagian besar tokoh-tokoh masyarakat setempat memahami pentingnya menjadikan Desa Bleberan sebagai desa wisata. Hasil wawancara berikut menunjukkan adanya nilai kegigihan. Mantan Kepala Desa Bleberan mengemukakan:

"Dalam upaya merealisasikan mimpi menjadikan desa ini menjadi desa wisata banyak tantangan yang dihadapinya. Tantanganya adalah dari pemahaman masyarakat sendiri dan juga dari para tokoh masyarakatnya. Atas kegigihan para pemuka masyarakatnya yang berusaha keras untuk meyakinkan langkahlangkah yang harus dilakukan untuk

\footnotetext{
Hasil wawancara dengan Tri Harjono, Mantan Kepala Desa Bleberan, 24 Agustus 2017.

Hasil wawancara dengan Suharno, Kepala Dukuh Menggoran Desa Bleberan, 25 Agustus 2017.

Indy G. Khakim, 2008, Mutiara Kearifan Jawa Kumpulan Mutiara-mutiara Jawa Populer, Pustaka Kaona, Ngawen-Blora Jawa tengah, hlm. 168.

11 CFG Sunaryati Hartono, 1992, Hukum Ekonomi Pembangunan Indonesia, Binacipta, Bandung, hlm. 24.
} 
merealisasikan desa wisata, akhirnya inisiatif tersebut dapat terwujud". ${ }^{2}$

Salah satu pemilik tanah yang lahannya sebagian digunakan untuk pelebaran jalan menyatakan sebagai berikut:

"Suatu fakta bahwa awalnya dalam pembukaan wisata air terjun Sri Gethuk ini ada sebagian masyarakat yang keberatan jika tanah miliknya digunakan untuk jalan menuju wisata Sri Gethuk. Melalui rembugan dengan pihak pemerintah desa kemudian dan diberi pengertian arti pentingnya dibukanya pariwisata bagi masyarakat luas Desa Bleberan. Pihak desa berusaha menyadarkan agar warga secara ikhlas mendukung mewujudkan mimpi desa wisata. Karena pihak pemerintah desa gigih akhirnya kami mau tidak mau membolehkan juga sebagian tanah kami untuk pengembangan atau pembangunan wisata Sri Gethuk". ${ }^{13}$

Pemuka Masyarakat Desa Bleberan dalam mewujudukan cita-cita luhur yaitu menjadikan Desa Bleberan sebagai desa wisata dapat dikatakan diwujudkan dengan menggunakan prinsip gremetgremet waton slamet, alon-alon waton kelakon (merayapasal selamat, pelan-pelanasal kesampaian). Adapun maknanya nasihat ini adalah segala sesuatu tindak perbuatan tidak boleh terburu dan ceroboh, karena segala perbuatan itu diperlukan perhitungan dan kewaspadaan. ${ }^{14}$ Menurut Santosa peribahasa di muka sangat erat dan senafas maknanya dengan peribahasa aja nggege mangsa, kebat kliwat, ngangsa marake brahala, sabar subur. Artinya, cita-cita memang sangat perlu dikejar tetapi harus disertai kesabaran dan jangan sampai ceroboh. ${ }^{15}$ Para pemuka Desa Bleberan dalam pengelolaan wisata terutama pada tahap awal akan dibukanya objek wisata menunjukkan kegigihannya dalam mewujudkan mimpi untuk membuka objek wisata. Konsep budaya Jawa tersebut disebut ora mingkuh (tidak mundur) dalam menghadapi tantangan.

\section{c. Nilai Kebersamaan}

Manusia memerlukan perhatian dan pertolongan orang lain dalam menjalani kehidupan. Manusia merupakan makhluk sosial (zoon politikon) sehingga manusia dan masyarakat dapat dikatakan dua hal yang komplementer. ${ }^{16}$ Berdasarkan hasil wawancara yang dilakukan berikut dapat dikatakan sebagai fakta bahwa pengelolaan wisata Desa Bleberan mengindikasikan adanya eksistensi nilai kebersamaan:

"Upaya para pemuka masyarakat dan didukung oleh segenap warga Masyarakat Desa Bleberan dalam mewujudkan desa wisata di wilayahnya tidak lepas dari adanya gotong-royong atau kekompakan dan pengorbanan semua elemen masyarakatnya.. Dukungan warga masyarakat ini terutama saat awal berjalannya upaya mewujudkan desa wisata. Warga masyarakat rela bergotong-royong membuat atau perbaikan jalan yang menuju lokasi wisata atau keikhlasan warga masyarakat yang sebagian tanahnya digunakan untuk jalan". ${ }^{17}$

Berkaitan dengan keberadaan desa wisata di wilayah Bleberan ini, menujukkan bahwa warga masyarakat ini akhirnya bisa menyadari adanya kepentingan umum yang lebih diutamakan dari pada kepentingan pribadi sehingga warga desa ini mau berkorban untuk kepentingan bersama. Konteks Masyarakat Desa Bleberan dapat dikatakan masih memegang teguh dan mengutamakan nilai kebersamaan dibandingkan dengan

\footnotetext{
Hasil wawancara dengan Tri Harjono, Mantan Kepala Desa Bleberan, 24 Agustus 2017.

13 Hasil wawancara dengan Hasil wawancara dengan Yabidi, Tokoh Masyarakat Desa Bleberan dan pemilik tanah yang digunakan untuk jalan pembangunan Wisata Sri Gethuk, 11 September 2017.

Iman Budhi Santosa, 2010, Nasihat Hidup Orang Jawa, Diva Press, Yogyakarta, hlm. 147-148.

Loc.cit.

Sudikno Mertokusumo, 2008, Mengenal Hukum Suatu Pengantar, Liberty, Yogyakarta, hlm. 3.

Hasil wawancara dengan Yubidi, Tokoh Masyarakat Desa Bleberan dan warga yang tanahnya sebagian digunakan jalan, 11 September 2017.
} 
mementingan kepentingan pribadi. Berkaitan dengan nilai kebersamaan ini, Roqib mengemukakan bahwa dalam konteks sosial, orang Jawa mementingkan kebersamaan. Masalah ini tersirat dari prinsip mangan ora mangan waton kumpul (makan tidak makan asal kumpul atau bersama). Prinsip ini sangat bermanfaat untuk menciptakan keharmonisan hubungan antara warga masyarakat satu dengan lainnya. ${ }^{18}$

\section{d. Nilai Musyawarah}

Menurut Abbas dalam musyawarah tercermin adanya kontrol diri karena dalam musyawarah mengharuskan para pihak samasama mundur selangkah guna sama-sama mencapai kemenangan (win-win solution). Artinya dalam proses musyawarah ini diperlukan pengendalian diri terhadap sifat rakus, menang sendiri dan tidak menghargai hak-hak orang lain ${ }^{19}$. Dalam musyawarah para pihak yang terlibat harus memiliki kemampuan ngunjara setan (memenjarakan setan). Istilah ini mempunyai maksud mengendalikan hawa nafsu. ${ }^{20}$ Berdasarkan wawancara di lapangan nilai musyawarah ini nampak dalam pernyataan di bawah ini:

"Apabila dilacak sejak awal sampai saat sekarang ini dalam mengelola wisata Sri Gethuk segala sesuatu masalah yang dihadapi selalu ditempuh melalui rembugan (musyawarah). Pada umumnya suatu keputusan akan dianggap sah dan kuat (legitimate) jika melalui musyawarah. Tanpa melalui jalur rembugan dapat dipastikan suatu putusan kurang atau tidak akan dapat dukungan yang memadai. Apabila tanpa musyawarah masyarakat disini merasa kurang diwongke karena tidak diajak rembugan. Ketika musyawarah dilakukan dapat dikatakan segala masalah akan dapat diselesaikan". ${ }^{21}$

Nilai musyawarah masih melekat dalam lingkungan Masyarakat Desa Bleberan. Semua elemen masyarakat masih percaya dan menyakini bahwa nilai luhur dari nenek moyang yang berupa nilai musyawarah dalam mencari solusi segala persoalan yang dihadapi masih sangat bermanfaat. Oleh karena itu, nilai musyawarah ini dijadikan sarana utama untuk mencapai permufakatan. Menurut Koesnoe musyawarah itu menunjuk kepada pembentukan kehendak bersama dalam urusan yang menyangkut kepentingan hidup bersama di dalam masyarakat sebagai keseluruhan. Berbeda dengan mufakat, karena menunjuk kepada pembentukan kehendak bersama. Berdasarkan kehendak bersama ini nantinya akan terwujud dalam aktifitas kerja bersama atau gotong-royong. ${ }^{22}$

\section{e. Nilai Lokalitas}

Pengelolaan objek pariwisata Sri Getuk sejak semula hanya melibatkan penduduk setempat (asli). Semua aktifitas untuk pelayanan dalam rangka mendukung penyambutan tamu wisata Sri Gethuk diupayakan menerapkan nilai lokalitas. Hal ini ditegaskan oleh tokoh Desa Bleberan dan Kepala Dukuh Menggoran menyatakan sebagai berikut:

"Dalam rangka pengelolaan wisata air terjun Sri Gethuk memang yang dilibatkan dibatasi orang-orang yang memiliki kartu penduduk atau warga penduduk Desa Bleberan saja. Masalah ini dijadikan pedoman atau aturan dalam pengelolaan objek wisata ini. Hal ini dikarenakan tujuannya adalah untuk kesejahteraan masyarakat Desa Bleberan, sehingga jangan sampai

\footnotetext{
18 Moh. Roqib, 2007, Harmoni Dalam Budaya Jawa (Dimensi Edukasi dan Keadilan Gender), Pustaka Pelajar, Yogyakarta, hlm. 60-61.

19 Syahrizal Abbas, 2009, Mediasi Dalam Perspektif Hukum Syariah, Hukum Adat, dan Hukum Nasional, Prenada Media group, Jakarta, hlm. 279.

20 Pardi Suratno dan Henniy Astiyanto, 2004, Gusti Ora Sare 65 Mutiara Nilai Kearifan Budaya Jawa, Adiwacana, Yogyakarta, hlm. 161-162.

21 Hasil wawancara dengan Ketua Unit Pengembangan Wisata BUM Desa Bleberan, 26 Agustus 2017, dan Hasil wawancara dengan Yabidi, Tokoh Masyarakat Desa Bleberan dan pemilik tanah yang digunakan untuk jalan pembangunan Wisata Sri Gethuk, 11 September 2017.

22 Moh. Koesnoe, 1979, Catatan-catatan Terhadap hukum Adat Dewasa Ini, Airlangga University Press, Surabaya, hlm. 46-48.
} 
warga Bleberan hanya sebagai penonton. Intinya baik karyawan atau pengelola maupun pedagangnya hanya dibatasi khusus warga Desa Bleberan".

Berdasarkan pernyataan tersebut, terlihat jelas bahwa nilai lokalitas sangat dijunjung tinggi dan diterapkan dalam pengelolaan wisata Sri Gethuk. Nilai lokalitas ini sejalan dengan prinsip negara mawa tata, desa mawa cara (negara-kota dengan aturan, desa dengan adat-istiadatnya sendiri). ${ }^{23}$ Masalah pembatasan ini bertujuan agar warga Desa Bleberan dapat mendapat nilai tambah atas dibukanya wisata Sri Gethuk. Kebijakan ini untuk memproteksi warga Bleberan jangan sampai hanya sebagai penonton atau menjadi kuli di wilayahnya sendiri. Kebijakan yang dilakukan pengelola wisata ini dapat dikatakan menerapkan prinsip hukum auto poietik karena hukum atau aturan yang dibuat tidak didikte dari luar, melainkan karena melalui proses-proses otonom dalam dirinya sendiri. ${ }^{24}$

Limitasi dalam pengelolaan wisata tersebut tidak dapat dilepaskan dengan adanya kekuranganya. Salah satunya adalah dalam hal sumber daya manusia. Sumberdaya yang ada di wilayah ini faktanya sangat terbatas sehingga membawa akibat perkembangan wisata Sri Gethuk ini kurang begitu signifikan dan agak kurang cepat. Para wisatawan mestinya tidak cukup hanya diberi pelayanan wisata air terjun saja tetapi seharusnya dapat diberikan pula dengan penyediaan cendera mata atau oleh-oleh yang menarik sebagai kenangan dari wisata Sri Gethuk. Bagi para pengelola wisatapun masih diperlukan pengetahuan tentang manajemen yang lebih baik lagi sehingga pengelolaan wisata air terjun ini menjadi tertata dan akuntabel.

\section{f. Nilai Religius}

Suatu tradisi yang merupakan kearifan lokal dan masih bergaung dalam kehidupan masyarakat Jawa sebagian ada yang tertulis dalam karya sastra tetapi sebagian lainnya bertahan dan berkembang melalui tradisi tutur tunular. ${ }^{25}$ Menurut Endraswara tradisi lisan (oral tradition) merupakan unsur penting dalam budaya Jawa karena merupakan bentuk pancaran pemikiran orang Jawa sehingga dapat dijadikan pedoman hidup. ${ }^{26}$ Menurut Tol dan Pudentia dalam Endraswara dinyatakan bahwa budaya lisan diantaranya mencakup cerita rakyat (folktales), legenda (legends) dan mitos (myths). ${ }^{27}$ Berdasarkan wawancara dengan mantan Kepala Desa Bleberan dan salah satu tokoh masyarakat desa tersebut dinyatakan bahwa berkaitan nama Sri Gethuk diceritakan sebagai berikut: $^{28}$

"Salah satu ciri khas desa pada umumnya terdapat mitosnya. Salah satunya di wilayah ini sejak zaman dahulu (Sri Gethuk) dipercaya ada penunggunya. Penunggunya senang dengan alat musik, sepertinya gamelan. Sampai sekarang masyarakat setempat masih sering mendengar dan hal itu bisa dibuktikan. Dahulu terdapat orang yang dapat pinjam alat gamelan itu, bentuk dari alat gamelan itu bulat yang bernama kethuk. Akhirnya nama Sri gethuk itu, asal muasalnya dipercaya dari alat musik gamelan yang bernama kethuk tadi dan dikombinasikan dengan istilah Srimanganti (pintu) sehingga menjadi Sri Gethuk. Selain itu, wilayah air terjun itu terkenal

\footnotetext{
S. Tartono, 2009, Pitutur Adi Luhur Ajaran Moral dan Filosofi Hidup Orang Jawa (Edisi Yang Disempurnakan), Yayasan Pustaka Nusatama, Yogyakarta, hlm. 410-411.

Derita Prapti Rahayu, 2014, Budaya Hukum Pancasila, Thafa Media, Yogyakarta, hlm. 86. Sri Wintala Achmad, 2014, Ensiklopedia Kearifan Jawa, Araska, Yogyakarta, hlm. 16.

Suwardi Endraswara, 2005, Tradisi Lisan Jawa Warisan Abadi Budaya Leluhur, Narasi, Yogyakarta, hlm. 2-3.

Loc.cit.

Hasil wawancara dengan Tri Harjono, Tokoh Masyarakat Desa Bleberan, 24 Agustus 2017, dan Suharno, Tokoh Masyarakat Desa Bleberan, 25 Agustus 2017.
} 
angker juga". ${ }^{29}$

Berdasarkan hasil wawancara tersebut, mengindikasikan bahwa dalam pengelolaan objek wisata Air Terjun Sri Gethuk terdapat nilai religius yang eksis. Dengan lain kata, pengelolaan wisata Sri Gethuk ini dapat berjalan sampai saat ini tidak dapat dilepaskan adanya mitos yang ada di wilayah wisata. Aspek nilai religius ini kenyataannya masih dapat dijadikan sarana menjaga kelestarian wisata Sri Gethuk. Masyarakat Desa Bleberan sebagian besar masih percaya adanya mitos yang ada di wilayahnya, sehingga masyarakat tidak berbicara maupun berprilaku tidak pantas. Mereka percaya bahwa berbicara maupun berprilaku tidak pantas dalam kehidupan sehari-hari akan terkena karma.

Terdapat mitos lain yang masyarakat percayai yaitu Wisata Air Terjun Sri Gethuk sebagai tempat pusat para jin yang suka dengan kesenian diantaranya drumband dan gamelan. Pada saat tertentu tempat ini sering terdengar suara kerawitan atau gamelan tetapi jika didekati suara itu tidak ada. Air Terjun Sri Gethuk ini dipercaya sebagai tempat penyimpanan salah satu alat gamelan yang disebut kethuk, akhirnya menjadi nama Sri Gethuk. ${ }^{30}$ Berdasarkan buku kecil tersebut juga diinformasikan tentang mitos asal usul nama Bleberan, upacara ritual nyadran setiap bulan Ruwah sebagai bentuk penghormatan leluhur dan upacara tumpeng robyong untuk memperingati masa perang dengan penjajah dan upacara rasulan, bersih desa, merti desa. Upacara merti desa ini pada hakikatnya bentuk rasa syukur masyarakat desa atas hasil panen yang diperoleh.

\section{Solusi Jika Terjadi Benturan Nilai Dalam Pengelolaan Wisata Sri Gethuk}

\section{a. Nilai Konservatif dan Nilai Inovatif}

Konservatif adalah kolot atau bersikap mempertahankan keadaan yang sudah ada, kebiasaan dan tradisi yang berlaku saat ini. ${ }^{31}$ Di samping itu, kata inovatif bersifat sebaliknya, yaitu memperkenalkan sesuatu yang baru atau adanya pembaharuan dari halhal sudah mapan, baik itu gagasan, alat atau metode). ${ }^{32}$ Menurut aspek etis konservatif artinya sikap untuk mempertahankan sistem dan praktik etis yang ada, melawan pandangan serta kehidupan etis yang baru. ${ }^{33}$ Apabila dikaitkan dengan data di lapangan, nilai konservatif dan nilai inovatif nampak melekat dalam pengelolaan wisata Sri Gethuk dari hasil wawancara sebagai berikut:

"Memang harus diakui gagasan awal dan dukungan awal untuk menangkap peluang menjadikan desa wisata terutama orang-orang dan tokoh masyarakat yang memiliki sikap pembaharu dan terbuka wawasannya. Orang-orang yang inovatif ini seperti Bapak Sukandi dan Bapak Tri Harjono, sedangkan di sisi lain ternyata ada juga orang-orang pada umumnya rakyat biasa yang pasrah atau manut saja. Bahkan pada awalnya ada yang tidak setuju dibukanya desa wisata di Bleberan ini. Orang-orang yang tidak setuju mempunyai pandangan bahwa keadaan sudah aman dan tenteram, mengapa repot-repot membuat masalah baru nantinya". ${ }^{34}$

Berdasarkan fakta tersebut mengindikasikan bahwa dalam pengelolaan wisata Sri Gethuk tidak dapat dielakkan adanya benturan pilihan nilai antara nilai konservatif dengan nilai inovatif. Para

\footnotetext{
Hasil wawancara dengan Suharno, Kepala Dukuh Menggoran Desa Bleberan, 25 Agustus 2017.

Tri Harjono, 2012, Legenda dan Budaya Desa Bleberan, Desa Bleberan, Wonosari-Gunungkidul, hlm. 11.

Kamus Besar Bahasa Indonesia, "konservatif", https://kbbi.web.id/konservatif.html, diakses 20 September 2017.

Departemen Pendidikan dan Kebudayaan, 1990, Kamus Besar Bahasa Indonesia, Balai Pustaka, Jakarta, hlm. 333.

A. Mangunhardjana, 1997, Isme-isme Dalam Etika dari A sampai Z, Kanisius, Yogyakarta, hlm. 130.

Hasil wawancara dengan Purwanto, Tokoh Masyarakat Desa Bleberan, 15 September 2017, Hasil wawancara dengan Suharno, Dukuh
} 
tokoh masyarakat Desa Bleberan yang sudah memiliki ilmu dan pengalaman lebih luas dapat menangkap peluang untuk meningkatkan kesejahteraan masyarakat melalui sarana membuka wilayahnya dijadikan desa wisata. Di sisi lain, mimpi atau keinginan untuk membuka objek wisata di daerah Bleberan inipun mendapatkan tantangan dari warga masyarakat yang kurang responsif terhadap gagasan pembukaan desa wisata di wilayahnya tersebut.

Perbedaan pandangan terhadap nilai antara konservatif dan inovatif dalam perjalanan pengelolaan wisata Sri Gethuk dapat diakomodasi secara sinergis sehingga tidak menimbulkan goncangan dalam kehidupan masyarakat Desa Bleberan. Faktanya sampai saat ini masyarakat semakin lama semakin banyak yang cenderung mendukung nilai inovatif karena banyak membawa kemanfaatan bagi kehidupan masyarakat. Misalnya, dapat dijadikan akses menambah penghasilan, menambah pengalaman dalam pergaulan, meningkatkan PAD desa atau dapat mempromosikan keunikan wilayah Desa Bleberan. Artinya nilai inovatif dapat diterima oleh masyarakat jika nilai tersebut dapat membuktikan membawa dampak kemanfaat bagi masyarakat.

Situasi menguatnya nilai inovatif dalam kehidupan masyarakat dapat mengubah mental dengki menjadi mental bekti. Mental dengki ini merupakan penyakit hati, perilaku pendengki biasanya penuh kepura-puraan dan bahkan sering menetang atau mengancam pihak yang dibencinya. Bagi para pemuka masyarakat secara normal mempunyai beban untuk mendorong dan mengarahkan mental dengki ini kearah mental bekti. Mental bekti merupakan sikap yang menerima, patuh dan hormat terhadap pihak lain yang dipandang memiliki kelebihan. ${ }^{35}$

\section{b. Nilai Religius dan Nilai Materialistik}

Materialisme merupakan paham yang menyatakan bahwa hakekat kebenaran itu harus dapat diterima akal dan dapat dibuktikan secara empiris. Oleh karena itu, ukuran secara kuantitas sangat signifikan dalam menilai sesuatu. Paham materialisme ini dipercaya akan mendorong manusia dalam mencapai kesejahteraan material yang maksimal. ${ }^{36}$ Berbeda dengan materialistik, nilai religius ini memiliki karakteristik atau orientasi mendahulukan kepentingan segala sesuatu dalam rangka ibadah. Bagi orang yang menerapkan nilai religius, maka kepentingan yang berorientasi kepada materi harus dikalahkan jika bertentangan dengan nilai religius.

Pengelolaan pariwisata di Desa Bleberan yang kental dengan syarat religiusitas mendapatkan gesekan atau desakan nilai materialistik. Alam pikiran yang berorientasi kepada kebendaan atau bendawi (nilai materialistik) mulai terasa mulai hadir dalam kaitannya pengelolaan wisata. Persoalan yang berkaitan dengan dikotomi antara nilai religius dengan nilai materialistik dapat dibuktikan melalui hasil wawancara di bawah ini:

"Dalam hal membuka berbagai fasilitas untuk wisata Sri Gethuk terutama jalan untuk akses ke lokasi wisata, pada awal mulanya dengan mengerahkan warga sekitar dengan kerja bersama atau gugur gunung. Kepala desa melalui kepala dukuh mengkoordinasikan kerja bersama tersebut. Setelah jalan ada, kemudian desa mengajukan proposal untuk pembangunan jalan selain penambahan beberapa fasilitas. Namun untuk pengelolaan wisata Sri Gethuk sejak awal tanah yang

Menggoran, 25 Agustus 2017, dan Hasil wawancara dengan Muhammad Al Kohar, Tokoh Pemuda,15 September 2017.

Suwardi Endrawara, 2015, Revolusi Mental Dalam Budaya Jawa, Narasi, Yogyakarta, hlm.88-93.

Hudiyanto, 2002, Keluar Dari Ayun Pendulum Kapitalisme Sosialisme, Pusat Pengembangan Ekonomi UMY, Yogyakarta, hlm. 33. 
milik Dinas Kehutanan kita tidak dengan cuma-cuma karena harus menyewa kepada Dinas Kehutanan dengan membayar sejumlah uang tertentu. Di samping itu, untuk lahan peroranganpun pihak pengelola juga memberikan uang tanda terima kasih walaupun tidak mesti". ${ }^{37}$

"Sebagai salah satu staf di Panitikismo Kraton Ngayogyokarto sampai saat ini tidak mempermalahkan Sulthanat Grond untuk wisata. Namun seharusnya tahu sendiri." ${ }^{.38}$

"Sebagian tanah saya yang digunakan untuk kepentingan wisata sri Gethuk saya ikhlaskan saja dan dikasih uang kerugian tetapi tidak layaklah karena tidak rutin. Seharusnya sebagai tanda terima kasih diberikan tanda terima kasih secara rutin". ${ }^{39}$

Berdasarkan wawancara yang dilakukan dengan sebagian subjek penelitian di atas, nampak bahwa nilai religius sangat dominan, karena warga masyarakat mau berkorban tanahnya demi kepentingan bersama digunakan untuk jalan menuju objek wisata air terjun. Demikian juga, para pemuka masyarakat mau mensosialisasikan dan meyakinkan secara terus-meneruskan tentang manfaat membuka lokasi wisata di wilayahnya. Pihak kratonpun tidak ketinggalan karena tanah Sulthanat Ground banyak digunakan untuk kegiatan pariwisata yang menghasilkan uang tetapi tidak memungut atau meminta bagian pendapatannya.

Nilai religius yang sudah dijadikan acuan oleh masyarakat Desa Bleberan dalam menjalani kehidupan, kini juga harus berhadapan dengan nilai materialistik. Para pemegang kuasa dan warga masyarakat mulai menunjukkan adanya dorongan pilihan ke arah nilai materialistik dalam kaitannya objek wisata air terjun Sri Gethuk. Simbol kemunculan nilai ini nampak ketika para pemegang kuasa mulai mempertimbangkan atau kalkulasi uang dalam kaitannya pengelolaan wisata.

Dampaknya uang yang semula dijadikan sebagai alat transaksi pasar, satuan hitung atau penyimpan kekayaan bergerak menjadi lebih luas menjadi alat yang penuh makna. Dalam hubungan ini, sesuai pendapat Douglas dalam Nugraha menyatakan uang itu tidak hanya dijadikan alat ekonomi tetapi fungsi uang dapat meluas menjadi simbol sosial budaya. ${ }^{40}$ Situasi seperti ini peranan para pemegang kuasa sangan signifikan dalam menemukan formula yang tepat dalam mengintegrasikan nilai-nilai yang saling antagonis sehingga menjadikan harmonis bagi kehidupan masyarakatnya.

\section{c. Nilai Legalistik dan Nilai Pragmatik}

Nilai legalistik cenderung kearah pemikiran positivistik hukum, yang memiliki asumsi dan karekteristik seperti memisahkan moral dan hukum, mengutamakan hukum tertulis atau kodifikasi, reduksionis dari sumbernya (masyarakat), dan mekanistik sehingga alurnya aturan dan logika. ${ }^{41}$ Paham pragmatisme memandang bahwa segala sesuatu dapat dikatakan benar asalkan sesuatu dapat membuktikan membawa akibat yang bermanfaat secara praktis. Fenomena nilai legalistik dalam pengelolaan wisata air terjun Sri Gethuk tercermin adanya pernyatan sebagai berikut:

\footnotetext{
Hasil wawancara dengan Tri Harjono, Mantan Kepala Desa Bleberan, 24 Agustus 2017, dan Hasil wawancara dengan Suharno, Dukuh Menggoran, 25 Agustus 2017.

38 Hasil wawancara dengan Junaidi, salah satu staf atau petugas di Panitikismo Kraton Yogyakarta, 9 September 2017.

39 Hasil wawancara dengan H. Hajid, Pengawas BUM Desa Bleberan dan salah satu pemilik lahan di sekitar Wisata Sri Gethuk, 26 September 2017.

40 Heru Nugroho, 2001, Uang Rentenir dan Hutang Piutang di Jawa, Pustaka Pelajar, Yogyakarta, hlm. 95.

41 Anthon F. Susanto, 2010, Ilmu Hukum Non Sistematik Fondasi Fulsafat Pengembangan Ilmu Hukum Indonesia, Genta Publishing, Yogyakarta, hlm. 88-89.
} 
"Setelah wisata air terjun Sri Gethuk diserahkan dan dimasukkan menjadi salah satu bagian usaha Badan Usaha Milik Desa (BUM Desa), maka tata aturannya semakin jelas karena ada aturannya secara tertulis. Bagaimana pengelolaan maupun pengembangannya, semuanya sudah diatur dan tunduk pada peraturan desa. Permasalahnya aplikasinya, peraturan yang sudah ada tersebut sudah benarbenar dijalankan atau belum". ${ }^{42}$

"Masalah wisata Sri gethuk sampai kini pihak Panitikismo belum memberikan kekancinganya. Seharusnya objek pariwisata itu sesuai dengan tata ruang daerah yang dirancang oleh Pemda. Jika tidak sesuai tata ruangnya seharusnya objek wisata itupun dapat dihentikan. Semua harus taat aturan atau undang-undang. Jika Sulthanat Grond digunakan untuk objek wisata seharusnya masalah izin untuk mendapatkan kekancingan dari Kraton harusnya segera diselesaikan." ${ }^{43}$

Di samping itu, nilai pragmatik dapat ditangkap berdasarkan wawancara sebagai berikut:

"Apabila ditinjau dari segi kepraktisan, memang jalan yang terbaik untuk masalah perizinan ini segera diselesaikan secara bijaksana. Walaupun secara aturan seharusnya izin dahulu baru dijalankan, tetapi kenyataan di lapangan kadang diperlukan kebijakan yang cenderung ke arah kepraktisan". ${ }^{4}$

"Sebetulnya segala hak ikhwal yang berkaitan dengan pengelolaan wisata Sri Gethuk sudah ada aturannya. Namun begitu jika belum diatur di dalam aturan peraturan desa, maka jalan yang ditempuh melalui musyawarah agar segala bentuk persoalan dapat diselesaikan." ${ }^{45}$
Berkaitan dengan nilai legalistik ini Kepala Desa Bleberan menyatakan bahwa:

"Berdasarkan data dan informasi yang masuk kepadaku memang sudah ada kerja sama dalam bentuk perjanjian sewa menyewa tanah milik atau yang dikuasai Dinas Kehutanan dan Perkebunan DIY. Buktinya Surat Perjanjian yang ditandatangani Pjs. Kepala Desa Bleberan Ibu Sri Kustini dengan pihak Kepala Dinas Kehutanan dan Perkebunan DIY Bapak Ir. Sutarto, MP, tertanggal 1 Juli 2015. Perjanjian sewa menyewa tersebut sangat legal karena didukung dengan Surat Keputusan Gubernur DIY Nomor 100/KEP/2015 tertanggal 8 Mei 2015 Tentang Persetujuan sewa menyewa tanah milik daerah di Desa Bleberan Kecamatan Playen Gunungkidul kepada Pemerintah Desa Bleberan. Adapun jangka waktunya lima tahun nanti jika jatuh tempo ditinjau lagi. Nilai sewa menyewanya setiap tahunnya tidak sama dari yang terendah sekitar Rp13.500.000,00, sampai dengan sewa yang tertinggi sebesar Rp20.000.000,00 per tahun." ${ }^{\$ 6}$

Perjanjian tersebut menunjukkan bahwa dalam membuat perjanjian, masyarakat berpedoman pada nilai legalistik. Terlebih lagi didukung adanya perhitungan prosentase tertentu yang mengakibatkan setiap tahun nilai sewa tanahnya menjadi berbeda karena mengalami kenaikan sebesar $10 \%$ (sepuluh persen) dari harga sewa sebelumnya yang disepakati. Kenaikan prosentase harga sewa ini mengindikasikan salah satu satu nilai legalistik bekerja di dalamnya, yaitu mekanistik, reduksionis dan sangat mengandalkan hukum tertulis.

Pengelolaan tanah wisata Sri Gethuk di Desa Bleberan dapat dinyatakan dalam membuat perjanjian cenderung menerapkan

\footnotetext{
Hasil wawancara dengan Ketua Unit Pengembangan Wisata BUM Desa Bleberan, 26 Agustus 2017.

Hasil wawancara dengan Junaidi, Petugas Panitikismo Kraton Yogyakarta, 9 September 2017.

Hasil wawancara dengan Junaidi, Petugas Panitikismo Kraton Yogyakarta, 9 September 2017.

Hasil wawancara dengan Ketua Unit Pengembangan Wisata BUM Desa Bleberan, 26 Agustus 2017.

Hasil wawancara dengan Supraptono, Kepala Desa Bleberan, 16 September 2017.
} 
nilai legalistik. Hal tersebut dikarenakan perjanjian dibuat secara tertulis dan sangat dijunjung tinggi untuk dijalankan, walaupun keadaan tidak seperti yang diprediksikan. Pentaatan hukum tertulis harus dinomorsatukan sehingga prinsip yang bekerja adalah semboyan fiat justitia pereat mundus, hukum (tertulis) harus ditegakan walaupun dunia binasa atau runtuh.

Selain itu, dalam pengelolaan wisata Sri Gethuk menandakan juga eksistensi nilai pragmatik yang dijalankan oleh para pemegang kuasa yang terkait dengan objek wisata ini. Berkaitan dengan masalah izin dalam pengeloaan wisata ini prosedur hukum yang seharusnya dilakukan dapat diberikan kebijakan demi kepraktisan. Salah satu tokoh masyarakat Desa Bleberan bahkan mengakui dan menegaskan bahwa segala sesuatu yang sudah diatur dalam aturan tertulis dari undang-undang sampai dengan peraturan desa tidak mungkin semuanya bisa masuk. Hal ini dikarenakan persoalan di masyarakat itu sangat komplek, sehingga jika ada masalah yang belum tertampung di aturan tertulis tersebut solusinya dengan musyawarah. Artinya pemuka masyarakat ini menyadari bahwa hukum tertulis tidak mungkin bekerja maksimal tanpa dibarengi dengan hukum tidak tertulis.

Pengelolaan wisata Sri Gethuk terutama yang berkiatan tanah harus diakui dalam perkembangan sampai saat ini cenderung berorientasi menjalankan nilai legalistik. Di sisi lain, nilai pragmatik kadang kala masih diperlukan untuk dijadikan acuan dalam memecahkan suatu persoalan dalam pengelolaan wisata Sri Gethuk. Harmonisasi dan antinomi nilai legalistik dan nilai pragmatik sangat ideal untuk dijadikan pedoman dalam pengelolaan wisata. Tanpa adanya harmonisasi yang memadai dalam pengelolaan wisata tersebut akan menjadikan kendala untuk perkembangan wisata.

\section{d. Nilai Lokalitas dan Nilai Asing}

Masyarakat pedesaan dalam kehidupan pada umumnya didasarkan solidaritas atau kerukunan atas kesamaankesamaan. Menurut Durkheim solidaritas seperti ini disebut solidaritas mekanik karena didasarkan pada suatu kesadaran kolektif. ${ }^{47}$ Berdasarkan modal solidaritas yang sudah berjalan ini, masyarakat Desa Bleberan menggunakan nilai lokalitas sebagai sarana dalam pengelolaan wisata. Masalah ini dapat dibuktikan dengan adanya kebijakan yang telah disepakati bersama mengenai para pihak yang berhak sebagai pengelola maupun yang ikut terlibat dalam pelayanan wisatawan di lingkungan wisata air terjun Sri Gethuk.

Para pihak yang diperbolehkan sebagai pengelola dan para pihak yang berhak memberikan pelayanan wisatawan dibatasi hanyalah warga Desa Bleberan. Artinya orang lain yang bukan warga Bleberan tidak dimungkinkan dapat berpartisipasi sebagai pengelola maupun memberi pelayanan wisatawan, seperti sebagai penjual dagangan, petugas parkir, pengusaha home stay atau pemandu wisata. Di samping itu, hasil yang diperoleh dari aktivitas ini disepakati selain untuk meningkatkan PAD desa juga untuk kesejahteraan masyarakat pada umumnya bukan hanya pengelolanya.

Selain itu, dalam perkembangannya tidak dapat dihindari kemunculan nilai asing atau nilai yang bukan berasal dari desa setempat. Berdasarkan wawancara salah satu tokoh agama dan sekaligus sebagai pengawas BUM Desa Bleberan dinyatakan sebagai berikut:

"Saya sebagai salah satu pengawas wisata Desa Bleberan memang pernah

Doyle Paul Johnson (Terjemahan: Robert M.Z. Lawang), 1994, Teori Sosiologi Klasik dan Modern, Jilid 1, PT Gramedia Pustaka, Jakarta, hlm. 183. 
menemukan adanya ketidakcocokan antara laporan dengan kenyataan dalam laporan pengelolaan wisata. Akhirnya pernah masyarakat melakukan demonstrasi meminta kejelasan. Selain itu, perkembangannya dalam pemberian tanda terima kasih kepada orang yang tanahnya digunakan untuk aktivitas wisata tidak diberikan secara rutin bahkan jika diberi nilainya sudah tidak layaklah. Jika begitu, jangan sampai kemakmuran dampak dari kegiatan wisata ini hanya dinikmati orang-orang tertentu saja." ${ }^{48}$

Berdasarkan wawancara tersebut, mengindikasikan bahwa masyarakat Desa Bleberan ternyata dalam memantau atau mengontrol pelaksanaan pengelolaan wisata cukup sensitif terhadap hal-hal yang kurang semestinya. Para pengelola wisata sebenarnya dapat dikategorikan sebagai visible leader (diakui massa dan pemimpin lain $)^{49}$ tetapi jika dalam menjalankan amanah tidak pada tempatnya masyarakat Desa Bleberan berani melakukan tindakan reaksi. Faktanya masyarakat Desa Bleberan mulai berani melakukan tuntutan adanya imbalan yang memadai bagi yang tanahnya digunakan aktivitas wisata dan juga melakukan demonstrasi karena adanya ketidakcocokan antara laporan dan kenyataan dalam hal penggunaan atau pengalokasian uang anggaran. Keberanian warga masyarakat dalam mengontrol pengelolaan wisata ini tidak dapat dilepaskan adanya pengaruh nilai asing terutama tentang keterbukaan atau transparansi.

Solusi yang dijalankan untuk menjaga harmoni kehidupan masyarakat Desa Bleberan akibat persoalan yang dihadapi adalah dilakukan melalui jalur musyawarah, baik untuk mengatasi masalah dalam ranah personal maupun sosial. Musyawarah ini masih dijadikan pilihan sarana solusi masalah karena dapat mengakomodasi nilai kebersamaan, pengorbanan, supernatural maupun keadilan. ${ }^{50}$ Berkaitan dengan masalah ini, sikap dan tindakan yang bersifat eklektik antara nilai lokalitas dan nilai asing sangat diperlukan untuk menjaga harmonisasi kehidupan masyarakat dalam pengelolaan wisata.

\section{Kesimpulan}

Desa Bleberan memiliki potensi sumber daya alam dan berhasil dijadikan menjadi objek wisata air terjun Sri Gethuk dikarenakan para pemuka masyarakatnya memiliki dan menerapkan nilai inovasi. Beruntungnya para pemuka masyarakat desa ini sangat gigih dalam memperjuangkan citacita (ora mingkuh) untuk menjadikan air terjun sebagai objek wisata. Selain itu, masyarakat memiliki orientasi nilai kebersamaan yang sangat terlihat pada saat dilakukan gotong-royong dalam pembuatan jalan menuju ke lokasi wisata. Selain itu, dalam pengelolaan sekarangpun juga tidak dapat dilepaskan nilai kebersamaan dalam menghadapi persoalan yang menghadang. Pengelolaan Wisata Air Terjun Sri gethuk sangat berorientasi kepada nilai musyawarah dalam memutuskan persoalan yang dihadapi dari awal pembukaan hingga pengelolaan saat ini.

Pengelolaan Wisata Air Terjun Sri Gethuk sudah membuktikan menggunakan landasan nilai lokalitas dalam membuat kebijakan atau aturan. Di wisata Sri Gethuk ini para pengelola dan warga yang terlibat pelayanan wisatawan di wilayah ini dibatasi hanya warga yang berdomisili di Desa Bleberan saja. Masyarakat Desa Bleberan dalam pengelolaan objek wisata air terjun Sri Gethuk, masih sangat memegang teguh nilai religius. Orientasi kepada nilai religius masyarakat ini terlihat adanya

\footnotetext{
Hasil wawancara dengan H. Hajid, Pengawas BUM Desa Bleberan dan salah satu pemilik lahan di sekitar Wisata Sri Gethuk, 26 September 2017.

49 Sunyoto Usman, 1998, Pembangunan dan Pemberdayaan Masyarakat, Pustaka Pelajar, hlm. 62.

50 Syahrizal Abbas, Op.cit., hlm. 243.
} 
mitos-mitos yang masih dipercaya di lingkungan masyarakat Desa Bleberan terutama mitos nama Sri Gethuk, makhluk halus yang menunggu air terjun dan asal usul nama serta nenek moyang Desa Bleberan.

Pada awalnya, sebagian Masyarakat di Desa Bleberan tidak memberikan tanggapan yang positif dalam pembukaan Wisata Air Terjun Sri Gethuk. Hal ini dikarenakan masyarakat ada yang berorientasi kepada nilai konservatif tetapi di sisi lain ada juga sebagian warga masyarakat memilih nilai inovatif. Atas usaha yang serius dan tidak mengenal putus asa dengan kearifan, nilai konservatif dapat disinergikan dengan nilai inovatif. Di samping itu, nilai religius dalam pengelolaan wisata Sri Gethuk dapat dijaga walaupun mendapatkan desakan nilai materialistik melalui kebijaksanaan pemuka masyarakat. Berdasarkan Pasal 7 Undang-Undang Nomor 13 Tahun 2012 tentang Keistimewaan Daerah Istimewa
Yogyakarta dan Peraturan Gubernur DIY Nomor 34 Tahun 2017 Tentang Pemanfaatan Tanah Desa memberikan landasan yuridis tentang keistimewaan dalam bidang tanah kepada Pemerintah DIY.

Peraturan tersebut menegaskan bahwa pemanfaatan tanah desa yang merupakan hak milik kasultanan atau kadipaten harus mendapatkan izin tertulis dalam bentuk Serat Kekancingan dengan hak anggaduh. Nilai legalistik ini bermanfaat untuk kepastian hukum tetapi dalam pelaksanaannya untuk wisata Sri Gethuk masih mengakomodasi nilai pragmatik. Nilai lokalitas yang sejak semula diyakini manfaatnya oleh masyarakat setempat, dengan dibukanya wisata Sri Gethuk mengalami tantangan nilai asing. Adapun nilai asing yang sempat nampak dalam pengelolaan wisata ini adalah nilai transparansi. Persinggungan antara nilai lokalitas dan nilai asing dapat diserasikan melalui jalur musyawarah.

\section{DAFTAR PUSTAKA}

\section{A. Buku}

Abbas, Syahrizal, 2009, Mediasi Dalam Perspektif Hukum Syariah, Hukum Adat, dan Hukum Nasional, Prenada Media group, Jakarta.

Achmad, Sri Wintala, 2014, Ensiklopedia Kearifan Jawa, Araska, Yogyakarta.

Ashofa, Burhan, 2001, Metode Penelitian Hukum, Rineka Cipta, Jakarta.

Bungin, M. Burhan, 2007, Penelitian Kualitatif Komunikasi,Ekonomi, Kebijakan Publik dan Ilmu Sosial Lainnya, Kencana Prenada Media Group, Jakarta.

Departemen Pendidikan dan Kebudayaan, 1990, Kamus Besar Bahasa Indonesia, Balai Pustaka, Jakarta.

Endraswara, Suwardi, 2005, Tradisi Lisan Jawa Warisan Abadi Budaya Leluhur, Narasi, Yogyakarta.

Harjono, Tri .2012, Legenda dan Budaya Desa Bleberan, Desa Bleberan, WonosariGunungkidul.
Hartono, CFG Sunaryati, 1992, Hukum Ekonomi Pembangunan Indonesia, Binacipta, Bandung.

Hudiyanto, 2002, Keluar Dari Ayun Pendulum Kapitalisme Sosialisme, Pusat Pengembangan Ekonomi UMY, Yogyakarta.

Johnson, Doyle Paul (Terjemahan: Robert M.Z. Lawang), 1994, Teori Sosiologi Klasik dan Modern, Jilid 1, PT Gramedia Pustaka, Jakarta.

Khakim, Indy G., 2008, Mutiara Kearifan Jawa Kumpulan Mutiara-mutiara Jawa Populer, Pustaka Kaona, Ngawen-Blora Jawa tengah.

Koesnoe, Moh., 1979, Catatan-catatan Terhadap hukum Adat Dewasa Ini, Airlangga University Press, Surabaya.

Mangunhardjana, A., 1997, Isme-isme Dalam Etika dari A sampai Z, Kanisius, Yogyakarta.

Mertokusumo, Sudikno, 2008, Mengenal Hukum Suatu Pengantar, Liberty, Yogyakarta.

Nugroho, Heru, 2001, Uang Rentenir dan Hutang 
Piutang di Jawa, Pustaka Pelajar, Yogyakarta, hlm. 95.

Rahayu, Derita Prapti, 2014, Budaya Hukum Pancasila, Thafa Media, Yogyakarta.

Roqib, Moh., 2007, Harmoni Dalam Budaya Jawa (Dimensi Edukasi dan Keadilan Gender), Pustaka Pelajar, Yogyakarta.

Santosa, Iman Budhi, 2010, Nasihat Hidup Orang Jawa, Diva Press, Yogyakarta.

Soekanto, Soerjono, 1999, Sosiologi Suatu Pengantar, PT Raja Grafindo Persada, Jakarta.

Suratno, Pardi, dan Henniy Astiyanto, 2004, Gusti Ora Sare 65 Mutiara Nilai Kearifan Budaya Jawa, Adiwacana, Yogyakarta.

Susanto, Anthon F., 2010, Ilmu Hukum Non Sistematik Fondasi Fulsafat Pengembangan Ilmu Hukum Indonesia, Genta Publishing, Yogyakarta.

Tartono, S., 2009, Pitutur Adi Luhur Ajaran Moral dan Filosofi Hidup Orang Jawa (Edisi Yang Disempurnakan), Yayasan Pustaka Nusatama, Yogyakarta.

Usman, Sunyoto, 1998, Pembangunan dan Pemberdayaan Masyarakat, Pustaka Pelajar.

\section{B. Makalah}

Maria SW Sumardjono, "Metodologi Penelitian Ilmu Hukum", Makalah, Universitas Gadjah Mada, Yogyakarta, 2007.

\section{Internet}

Kamus Besar Bahasa Indonesia, "konservatif", https://kbbi.web.id/konservatif.html, diakses 20 September 2017.

Kismadi, Kania, "7 Tempat Wisata di Gunungkidul Yang Tidak Boleh Dilewatkan Para Pencari Andrenalin",https://www.skyscanner.co.id/ berita/7-tempat-wisata-di-gunung-kiduljogja, diakses 04 April 2017.

Kurniawan, David "PAD Gunungkidul Kelebihan Target Rp 18.4 M", http://semarang. bisnis.com/read/20170330/9/93096/padgunungkidul-kelebihan-target-rp184-miliar, diakses 04 April 2017.

Sumadiyono, "PAD Gunungkidul: Pemkab Optimis Target 2016 Tercapai", http:// www.harianjogja.com/baca/2016/07/20/ pad-gunungkidul-pemkab-optimistis-target2016-tercapai-738456, diakses 04 April 2017.

\section{Dokumen Lain}

Hasil wawancara dengan Tri Harjono, Mantan Kepala Desa Bleberan, 24 Agustus 2017.

Hasil wawancara dengan Suharno, Kepala Dukuh Menggoran Desa Bleberan, 25 Agustus 2017.

Hasil wawancara dengan Ketua Unit Pengembangan Wisata BUM Desa Bleberan, 26 Agustus 2017.

Hasil wawancara dengan Tri Harjono, tokoh masyarakat Desa Bleberan, Kecamatan Playen, Kabupaten Gunungkidul, 24 November 2016.

Hasil wancara dengan Junaidi, salah satu staf atau petugas di Panitikismo Kraton Yogyakarta, 9 September 2017.

Hasil wawancara dengan Yabidi, Tokoh Masyarakat Desa Bleberan dan pemilik tanah yang digunakan untuk jalan pembangunan Wisata Sri Gethuk, 11 September 2017.

Hasil wawancara dengan Purwanto, Tokoh Masyarakat Desa Bleberan, 15 September 2017

Hasil wawancara dengan Muhammad Al Kohar, Tokoh Pemuda,15 September 2017.

Hasil wawancara dengan H. Hajid, Pengawas BUM Desa Bleberan dan salah satu pemilik lahan di sekitar Wisata Sri Gethuk, 26 September 2017. 